\title{
Features of Geochemical Migration of Chemical Elements after Technogenic Loading of Pyrogenic Nature
}

\author{
Buts Yu. V.
}

\author{
S. Kuznets Kharkiv National University of Economics, 9-A Nauky Av., 61166 Kharkiv, Ukraine
}

\author{
Article info: \\ Paper received: \\ The final version of the paper received: \\ Paper accepted online:
}

\author{
*Corresponding Author's Address: \\ butsyura@ukr.net
}

\begin{abstract}
The study of the concentration of trace metals in soils by atomic absorption analysis was carried out. The results indicate the transformation of their migration properties. The diversity and versatility of behavior of chemical elements in environmental components after the fire was noted. In different ecological conditions, it is possible to observe a wide range of quantitative values of geochemical migration or accumulation of any particular chemical element. Analytical results show that the contents of migrant elements, $\mathrm{pH}$ values, areas of incidents, which are approximately in the same conditions, but passed by the grass or upper fire differ quite tangibly. Trace metals that hit the environment can form difficult soluble hydroxides. In addition, in the soil solution, there is a probability of the formation of hydroxocomplexes with different amounts of hydroxide ions by metals. The range of precipitation of hydroxides and the region of predominance of soluble hydroxocomplexes have been studied by constructing concentration-logarithmic diagrams. On the basis of the calculations it can be argued that the influence of the technogenic loading of pyrogenic origin on the geochemical migration of trace metals takes place. The obtained calculations can be used to predict the geochemical migration of trace metals in soils after the man-made consequences of emergencies of pyrogenic origin.
\end{abstract}

Keywords: chemical element, hydroxocomplex, migration ability, concentration-logarithmic diagram.

\section{Introduction}

At present, in Ukraine, studies focused on studying the man-made load due to the action of the pyrogenic (literally "generated by fire") factor on the environment, are given insufficient attention to. At the same time, the number of natural fires and their consequences increases from year to year. In the process of the restoration of natural ecosystems, it is the soil that determines both the type of vegetation and the dynamics of plant communities; hence the influence of natural fires on the properties of soils is one of the important tasks in the field of soil science.

The purpose of this paper is to study the geochemical aspects of the accumulation of trace metals under the influence of the man-caused load of pyrogenic origin.

\section{Literature Review}

There is no single-valued explanation for the causes that affect the behaviour of trace elements, in particular trace metals (TM), under the influence of technogenic effects. Literature data analysis allows noting the diversity and versatility of the behaviour of chemical elements in the components of the environment after fire damage. At various environmental conditions, a wide range of quantitative values of geochemical migration or accumulation of any specific chemical element can be observed [1]. For example, the concentration of mercury in soil after a ground fire is from 27.3 to $64.3 \%$. The discrepancy is almost by a factor of 2.36 [2].

As a rule, anionogenic elements have the best migration characteristics. Naturally they exist in the form of anions and highly soluble salts. For example, these are molybdenum and boron. Cationogenic elements, like zinc, copper, manganese and cobalt, migrate in the form of cations in the composition of highly soluble salts, sols, complex compounds and salts of fulvic acids [3].

The bulk of TM, like $\mathrm{Cu}, \mathrm{Hg}, \mathrm{Cd}, \mathrm{As}, \mathrm{Pb}$, etc., migrates in the composition of dust and aerosols. But when it comes to single cases of the minor migrations of ore elements, like $\mathrm{Cr}, \mathrm{Ni}, \mathrm{Co}, \mathrm{Mg}$, etc., which most often passively accumulate in the lithogenous basis of burned and/or adjacent area, so the role of large dust particles [4] should be recognized. 
The type of fire and its intensity affect the migration of chemical elements. The higher firepower, the higher the quantitative parameters of the air migration of chemical elements. It is obvious that there are other factors that determine the behaviour of TMs in fires in ecosystems.

Analytical results showed that areas of fires being under approximately the same conditions but traversed by ground or crown fire differ significantly in the content of migrating elements $(\mathrm{mg} / \mathrm{kg})$ and $\mathrm{pH}$ values.

In a general crown fire, a number of chemical elements, for example, mercury, cadmium, selenium and artificial radionuclides are taken out of the fire zone, their contents are $30-45 \%$ of their concentration in the areas of a ground fire [2]. The $\mathrm{pH}$ value increases by $6-10 \%$. Undoubtedly, this is due to the increase in the amount of ash that has an alkaline reaction, but it could be partially removed from the soil cover of the burned area by aeolian or hydrological processes. For this reason, it is not possible to correctly establish the relationship between the amount of ash and the $\mathrm{pH}$ value in the burned areas in a given time after the fire. The above examples of geochemical migration processes convincingly evidence that in addition to the type of fire as a factor in the migration of chemical elements from burned areas, the state of light-combustible materials, namely, the moisture content of the forest litter, is played a presentable role. This allows us to formulate one more reason determining the behaviour of TMs in forest fires: the physical state of ground forest combustible materials also serves as one of the factors determining geochemical migration in a natural fire.

It is known that different plants accumulate different microelements in different ways. That is, the nature of the distribution of trace metals in terrestrial plant parts should be taken into account. This determines the quantitative indicators of geochemical migration of chemical elements in a fire. The most characteristic is the radial distribution of most TMs in the soil profile, including the upper soil horizons with interlayers of steppe mat and forest litter. And in this event there is a significant fluctuation of TM content in radial differentiation within the soil profile.

Burnout of the upper parts of steppe mat, mosses, lichens and forest litter is accompanied by a weak emission of migrating trace elements not only because the upper layers of surface combustible materials dry out faster than the lower ones, but also because in these horizons their elevated concentrations are in the lower intervals but not in the upper ones.

Consequently, it should be emphasized that the complex interaction of chemical elements with each other, the state of ground combustible materials and the distribution of elements in soil vertical profiles are responsible for the behaviour of chemical elements during fires in ecosystems.

In windless weather, during the spread of a fire in the ecosystem, the chemical elements held by the fiery convection current migrate vertically to the upper atmospheric layers and, as it cools, settle on the burned area. The wind promotes the spread of the smoke plume beyond the pyrogenically affected area. This also makes it possible to recognize the role of weather conditions as one of the factors determining the migration of chemical elements from burned areas. However, in our opinion, this factor can be applied only to small fires, since the general crown fires are accompanied by the formation of vortex air currents tightening cold air masses from the areas adjacent to the fire. At the same time a horizontal advection movement of the smoke plume in such fires can not only be predicted but also almost impossible to take into account during a fire. At the same time, dry and warm weather will be favourable for atmospheric migration, while foggy and rainy weather will facilitate the rapid washout and deposition of dust and aerosol particles of the smoke plume. All presented analyzed information allows confirming the existence of another factor, of which the spread of the smoke plume depends on during the fire in the ecosystem: weather conditions affecting the migration or accumulation of separate chemical elements within the burned area.

There is no doubt that the transformation of steppe mats, forest litter, mosses, lichens, etc. in various combustion products (ash, coal, dust, aerosols, etc.) under the influence of high temperatures, natural fires are able to affect the migration of all the chemical elements.

It is proved that in the components of natural systems chemical elements occur in different states: sorption, absorption, and complex organo-mineral compounds, etc. But, since it is referred to natural fires, and consequently high temperatures, I.V. Alekseenko [2] considers their behaviour as depending on the temperatures of their boiling and evaporation. He associates active migration of cadmium and mercury with their low boiling points, whereas in such TMs as copper, chromium, nickel and cobalt it is an order of magnitude higher, namely they tend to be geochemically accumulated in the lithogenous basis of the burned area $\left({ }^{\circ} \mathrm{C}\right): \mathrm{Hg}=357, \mathrm{As}=610, \mathrm{Cs}=690, \mathrm{Cd}=765, \mathrm{Zn}=907$, $\mathrm{Mg}=1107, \mathrm{~Pb}=1744, \mathrm{Mn}=2151, \mathrm{Sr}=1384, \mathrm{Cr}=$ $2482, \mathrm{Cu}=2595, \mathrm{Ni}=2732, \mathrm{~V}$ and $\mathrm{Co}=3000$.

However, manganese falls from the above trend: having a high boiling point, it easily migrates. On the other hand, the migration of arsenic is low, although sublimation of this chemical element already occurs at a temperature of $610^{\circ} \mathrm{C}$. The reason for the low values of this indicator can be staying of arsenic within the mineral part of the forest litter and an expressed close connection with iron. The behaviour of sodium and potassium, which accumulate in the soils of burned areas but have a low temperature gradient, does not correspond to this pattern too.

Thus, the analysis of the above data allows us to conclude that the behaviour of trace metals during fires in ecosystems depends on many factors, the main of which are the following: the type of fire, the state of forest fuels, weather conditions, the geochemical properties of chemical elements and the nature of their distribution in components of the ecosystem.

During fires, the top few centimeters of soil are exposed to high temperatures, so the most drastic changes occur in the litter and in the upper part of the humus horizon. In the process of combustion, there is a significant loss of soil organic matter. Under the influence of high temperatures during a fire, most of carbon from the organic substance is oxidized to gaseous forms (mainly $\mathrm{CO}_{2}$ ) and volatilizes. During intense fires, the organic matter of the above the soil surface horizons and the upper part of the humus horizon are destroyed while the formation of a large number of carbonate compounds of alkaline and alkaline-earth elements, which causes an increase in the $\mathrm{pH}$ response, takes place. As 
noted by Yu. M. Krasnoschekov, et al. [5], the shift in soil acidity after a fire can be very considerable, it was recorded events from $\mathrm{pH}=5.7-5.9$ before a fire to $\mathrm{pH}=$ 8.7 after passing a ground fire. Two months after the fire, $\mathrm{pH}$ of the surface horizon remains to be 8.0, and only in the burned areas 10 years after fire the reaction of the upper organogenic horizons is restored. In addition to the microelements, which are of vital significance for plants, entering soil after passing through fire, large amounts of $\mathrm{Fe}, \mathrm{Al}, \mathrm{Zn}, \mathrm{Mn}$ and other trace metals are supplied together with ash.

\section{Research Methodology}

Let us examine in more detail the conditions for the formation of mobile forms of trace metals in soils, which will allow us to conclude of their migration or accumulation in the geochemical environment.

Trace metals that enter the environment can form hardly soluble hydroxides. In addition, in the soil solution there is the possibility of the formation of hydroxocomplexes by metals with different amounts of hydroxide ions [1]. The range of precipitation of hydroxides and the ranges of the predominance of soluble hydroxocomplexes have been studied by plotting concentration-logarithmic diagrams (CLDs) [6]. The dissolution of metal hydroxide illustrated with the example of the formation of copper hydroxide and the formation of its complex compounds is described by three main reactions as follows:

$$
\begin{array}{lc}
\mathrm{Cu}(\mathrm{OH})_{2}=\mathrm{Cu}^{2+}+2 \mathrm{OH}^{-} ; & \lg \mathrm{K}_{\mathrm{s}}=-19.66 \\
(2-\mathrm{n}) \cdot \mathrm{OH}^{-}+\mathrm{H}^{+}=\mathrm{H}_{2} \mathrm{O} ; & \operatorname{lgK} \mathrm{w}_{\mathrm{w}}=14 ; \\
\mathrm{Cu}^{2+}+\mathrm{n} \cdot \mathrm{OH}^{-}=\mathrm{Cu}(\mathrm{OH})_{\mathrm{n}}{ }^{2-\mathrm{n}} ; & \lg \beta_{\mathrm{n}} .
\end{array}
$$

Lumped reaction:

$$
\begin{array}{lll}
\mathrm{Cu}(\mathrm{OH})_{2}+(2-\mathrm{n}) \cdot \mathrm{H}^{+}=\mathrm{Cu}(\mathrm{OH})_{\mathrm{n}}{ }^{2-\mathrm{n}}+(2-\mathrm{n}) \cdot \mathrm{H}_{2} \mathrm{O} ; \\
\operatorname{lgK}=\operatorname{lgK} \mathrm{S}_{\mathrm{s}}+\lg \beta_{\mathrm{n}}-(2-\mathrm{n}) \lg \mathrm{K}_{\mathrm{w}} ; \\
\mathrm{n}=1: & \mathrm{Cu}^{2+}+\mathrm{OH}^{-}=\mathrm{Cu}(\mathrm{OH})^{+} ; & \lg \beta_{1}=6.0 ; \\
\mathrm{n}=2: & \mathrm{Cu}^{2+}+2 \mathrm{OH}^{-}=\mathrm{Cu}(\mathrm{OH})_{2} ; & \lg \beta_{2}=13.18 \\
\mathrm{n}=3: & \mathrm{Cu}^{2+}+3 \mathrm{OH}^{-}=\mathrm{Cu}(\mathrm{OH})_{3}{ }^{-} ; & \lg \beta_{3}=14.42 \\
\mathrm{n}=4: & \mathrm{Cu}^{2+}+4 \mathrm{OH}^{-}=\mathrm{Cu}(\mathrm{OH})_{4}{ }^{2-} ; & \lg \beta_{4}=14.56
\end{array}
$$

To calculate the equilibrium constant of the total reaction, logarithms of the products of hydroxide solubility and the stability constants of metal complexes and hydroxide ions were used.

The equilibrium concentrations of metal-containing particles will be the following:

$$
\begin{array}{ll}
\lg \left[\mathrm{Cu}(\mathrm{OH})_{\mathrm{n}}{ }^{2-\mathrm{n}}\right]=\lg \mathrm{K}_{\mathrm{s}}+\lg \beta_{\mathrm{n}}-(2-\mathrm{n}) \cdot \lg \mathrm{K}_{\mathrm{w}}-(2-\mathrm{n}) \cdot \mathrm{pH} ; \\
\mathrm{n}=0: & \lg \left[\mathrm{Cu}^{2+}\right]=\lg \mathrm{K}_{\mathrm{s}}-2 \lg \mathrm{K}_{\mathrm{w}}-2 \mathrm{pH}=8.34-2 \mathrm{pH} ; \\
\mathrm{n}=1: & \lg \left[\mathrm{Cu}(\mathrm{OH})^{+}\right]=\lg \mathrm{K}_{\mathrm{s}}+\lg \beta_{1}-\lg \mathrm{K}_{\mathrm{w}}-\mathrm{pH}= \\
& =0.34-\mathrm{pH} ; \\
\mathrm{n}=2: & \lg \left[\mathrm{Cu}(\mathrm{OH})_{2}\right]=\lg \mathrm{K}_{\mathrm{s}}+\lg \beta_{2}=-6.48 \\
\mathrm{n}=3: & \lg \left[\mathrm{Cu}(\mathrm{OH})_{3}{ }^{-}\right]=\lg \mathrm{K}_{\mathrm{s}}+\lg \beta_{3}+\lg \mathrm{K}_{\mathrm{w}}+\mathrm{pH}= \\
& =-19.24+\mathrm{pH} ; \\
\mathrm{n}=4: & \lg \left[\mathrm{Cu}(\mathrm{OH})_{4}{ }^{2-}\right]=\lg \mathrm{K}_{\mathrm{s}}+\lg \beta_{4}+2 \lg \mathrm{K}_{\mathrm{w}}+2 \mathrm{pH}= \\
& =-33.1+2 \mathrm{pH} .
\end{array}
$$

Thus, from the diagrams shown in Figure 1, it is possible to clearly determine the ranges of maximum precipitation of metal hydroxides. The condition for the precipitation of $\mathrm{Me}^{\mathrm{z}+}$ is considered that it achieves concentration of the order of $10^{-5} \mathrm{~mol} / \mathrm{l}$ in the soil solution. From Figure 1, at $\mathrm{pH} \leq 6.8$, copper is in a dissolved form, at higher $\mathrm{pH}$ values, copper precipitates in the form of hydroxide $\mathrm{Cu}(\mathrm{OH})_{2}$, and at very high levels $(\mathrm{pH}>13)$, hydroxocomplexes $\mathrm{Cu}(\mathrm{OH})_{3}$ are formed but their concentration is very low, which allows us to conclude that copper compounds in neutral medium have a high migration capacity and their fixation at $\mathrm{pH} \geq 6.8$. Calculations have been made and corresponding diagrams have been plotted for a number of other metals.

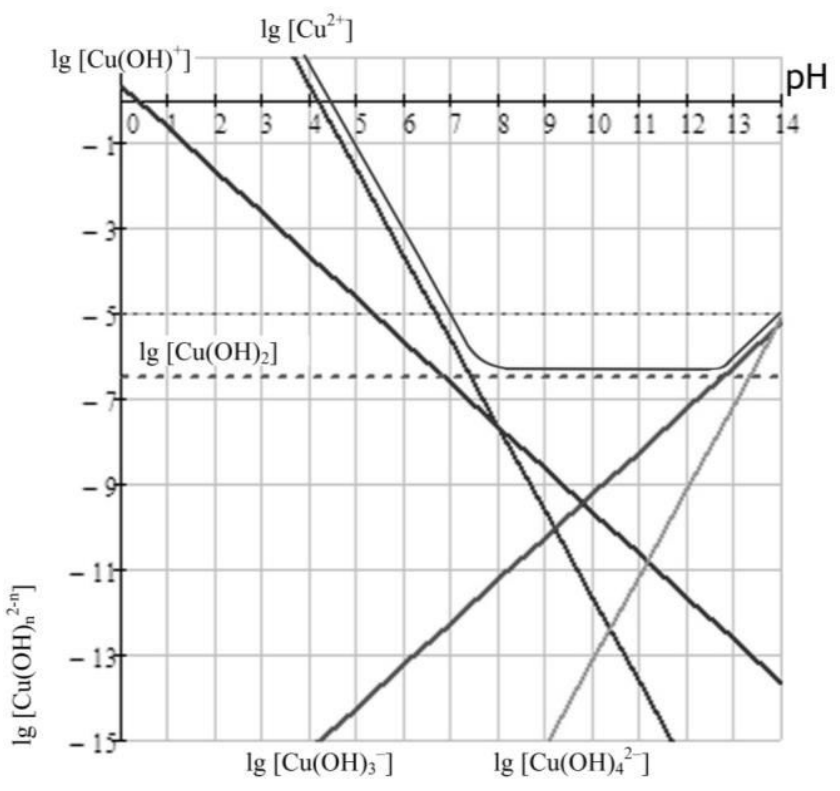

Figure 1 - The concentration-logarithmic diagram (CLD) of forming copper hydroxocomlexes

\section{Results}

The precipitation ranges of hydroxides calculated by us with the aid of CLDs are in good agreement with the experimental data obtained by Yu. Lurie [7].

In neutral soil, most metals, such as $\mathrm{Al}, \mathrm{Cr}, \mathrm{Zn}, \mathrm{Cu}$, $\mathrm{Fe}$ (II), Co and $\mathrm{Ni}$, are in hardly soluble forms (in the forms of hydroxides), at this their migration capacity is not large, which leads to the accumulation of chemical elements in soils. Under such conditions, trace metals are not washed out of soils, they are not assimilated by plants, instead their accumulation in soils occurs [1].

If a significant shift in $\mathrm{pH}$ occurs, as for example was recorded by Yu.M. Krasnoschekov et al. [5], the behaviour of copper compounds will change dramatically. At $\mathrm{pH}=5.7$ before the fire, the concentration of $\left[\mathrm{Cu}^{+2}\right]=0.01 \mathrm{~mol} / \mathrm{l}$, at $\mathrm{pH}=8.7$ after the fire, all copper in an insoluble form will accumulate in soils.

$\mathrm{Fe}^{2+}$ ions migrate easily in acidic, neutral and even slightly alkaline medium up to $\mathrm{pH}=9.5$, and only in strongly alkaline medium hydroxide $\mathrm{Fe}(\mathrm{OH})_{2}$ is formed. 


\section{Conclusions}

On the basis of our calculations, it can be argued that the effect of the man-made load of pyrogenic origin on the geochemical migration of trace metals takes place. Compounds of $\mathrm{Fe}^{3+}$ at $\mathrm{pH}=4.5-14.0, \mathrm{Cu}^{2+}$ at $\mathrm{pH}=7-14$, $\mathrm{Cr}^{2+}$ at $\mathrm{pH}=7-9, \mathrm{Zn}^{2+}$ at $\mathrm{pH}=8-11, \mathrm{Ni}^{2+}$ at $\mathrm{pH}=8-14$, $\mathrm{Pb}^{2+}$ at $\mathrm{pH}=9-12, \mathrm{Fe}^{2+}$ at $\mathrm{pH}=9.5-14$ have the lowest migration abilities. In a more acidic environment, soluble substances are formed, but with an increase in $\mathrm{pH}=0.5$ 1.0 only, their mobility can decrease by an order of magnitude, which contributes to their concentration in soils after fire.
In neutral in their reaction soils most of trace metals, like $\mathrm{Cr}, \mathrm{Zn}, \mathrm{Cu}, \mathrm{Fe}$ (II), Ni, are in hardly soluble forms as hydroxides, at this their migratory abilities are low, which leads to accumulation of these elements in soils.

Trace metals, which are mobile in a neutral medium, such as $\mathrm{Fe}$ (II), Cd, Co, Mg and Mn should be allocated in a separate group. Any increase in the level of $\mathrm{pH}$ facilitates their fixation.

The calculation results obtained can be used to predict the geochemical migration of trace metals in soils in consequence of the man-made emergencies of pyrogenic origin.

\title{
References
}

1. Buts, Yu. V., \& Krayniuk, E. V. (2017). Geochemical transformation of migration properties of heavy metals under the influence of technogenic loading of pyrogen. Ecological Safety, Vol. 24, pp. 95-100 [in Ukrainian].

2. Alekseenko, I. V., \& Gamova, N. S. (2015). Influence of forest fires on the properties of soils of taiga landscapes of the Khamar-Daban ridge. Biogeochemistry of Technogenesis and Modern Problems of Geochemical Ecology, Vol. 1, pp. 171-174 [in Russian].

3. Trofimov, I. T., \& Bakharev, I. Yu. (2007). Peculiarities of post-pyrogenic transformation of sod-podzolic soils in the southwestern part of bandar forests of the Altai Territory. Bulletin of the AGAU, No. 11(37), pp. 31-35 [in Russian].

4. Bryanin, S. V. (2014). Migration and accumulation of ash elements in forest landscapes under the influence of periodic fires on the Amur-Zeisk plain. Fundamental Studies, Vol. 8, pp. 859-863 [in Russian].

5. Krasnoschekov, Yu. N., Valendik, Ye. N., Bezkorovajnaja, I. N., Verhovec, S. V., Kisiljahov, E. K., \& Kuz'michenko, V. V. (2005). Influence of controlled burning of silk crackers on the properties of sod-podzolic soils in Nizhny Novgorod. Forestry, Vol. 2, pp. 16-24 [in Russian].

6. Goronovskiy, I. T., Nazarenko, Yu. P., \& Nekryach, Ye. F. (1974). Brief Chemical Handbook. Kyiv, Naukova Dumka [in Russian].

7. Lurie, Yu. (1989). Handbook on Analytical Chemistry. Moscow, Chemistry [in Russian].

\section{Особливості геохімічної міграції хімічних елементів при техногенному навантаженні пірогенного характеру}

\author{
Буц Ю. В.
}

Харківський національний економічний університет ім. С. Кузнеця, просп. Науки, 9-А, 61166, м. Харків, Україна

\begin{abstract}
Анотація. Відзначено різноманітність поведінки хімічних елементів у довкіллі після ураження пожежами. Можна спостерігати широкий діапазон кількісних значень геохімічної міграції або акумуляції хімічного елемента. Важкі метали, що потрапили у довкілля, можуть утворювати гідроксиди або гідроксокомплекси, від яких залежить міграційна здатність. Діапазон осадження гідроксидів та області переважання розчинних гідроксокомплексів вивчені за допомогою побудови концентраційно-логарифмічних діаграм. Створено прогнозування геохімічної міграції сполук міді у грунтах після пірогенного впливу. На підставі розрахунків можна стверджувати, що має місце вплив техногенного навантаження пірогенного характеру на геохімічну міграцію важких металів. Отримані розрахунки можна використовувати для прогнозування геохімічної міграції важких металів у грунтах після техногенних наслідків надзвичайних ситуацій пірогенного походження.
\end{abstract}

Ключові слова: хімічний елемент, гідроксокомплекс, міграційна властивість, концентраційно-логарифмічна діаграма. 